\title{
ОЦІНКА ЯКОСТІ ТА ВАРТОСТІ ДОРОГОЦІННОГО КАМІННЯ
}

\author{
В.В. ИНДУТНЫЙ, Н.В. МЕРЕЖКО, Н.В. КАЛУГА
}

Киевский национальный торгово-экономический университет

\section{ОЦЕНКА КАЧЕСТВА И СТОИМОСТИ ДРАГОЦЕННЫХ КАМНЕЙ}

\author{
V. INDUTNY, N. MEREZHKO, N. KALUGA \\ Kyiv National University of Trade and Economics
}

\section{ESTIMATION OF THE QUALITY AND VALUE OF GEMSTONES}

\section{https://doi.org/10.36910/6775-2310-5283-2018-11-08}

Мета. Дослідження основних засад щуодо формування спеціальних протоколів про якість та вартість дорогочінного каміння на ринку України, а також побудова математичної моделі для опису релячї «якість-вартість» при здійсненні операцій прогнозування їх вартості.

Методика. Для прогнозування вартості дорогоцінного каміння було використано стандартні методи регресійного аналізу.

Результати. Представлено результати аналізу розподілу питомих вартісних показників на дорогоџінні камені на ринку Украӥни. Виділено три товарознавчі групи якості для дорогоцінних каменів: камені задовільної якості, камені середньої якості, камені високої якості. Запропоновано універсальний індекс для очуінки якості дорогоцінних каменів, оснований на розрахунку кількості позитивної інформащії про них. Критерії для опису якості в термінах кількості позитивної інформації представлені в спеціальному протоколі. Запропоновано визначати прогнозовану вартість дорогочінних каменів $з$ урахуванням фінансових можливостей потенційних покупців. Представлено приклади визначення якості $i$ прогнозування вартості дорогоцінних каменів на основі запропонованого алгоритму.

Наукова новизна. Виділено три товарознавчі групи дорогоцінних каменів за якісними характеристиками та встановлено залежності між їх прогнозованою вартістю і порядком вартості.

Практична значимість. Розроблено спрощений підхід до обліку якісних характеристик каменів, методику визначення прогнозованої вартості дорогоцінних каменів, яка дає можливість обчислення прогнозних показників вартості на дорогоцінні камені з урахуванням двох факторів - аналізу ринку та врахування особливостей розподілу показників рівнів фінансових можливостей потенційних покупців.

Ключові слова: дорогочінне каміння, прогнозована вартість, універсальний індекс, спеціальний протокол. 


\section{Постановка проблеми у загальному вигляді і її зв'язок з важливими} науковими та практичними завданнями. Згідно з практикою XX століття оцінювання якості та сертифікація дорогоцінного каміння у всіх країнах світу здійснюється на основі спеціальних документів - технічних умов, які $\epsilon$ інтелектуальною власністю окремих осіб, незалежних гемологічних лабораторій та спеціалізованих державних установ [8,13,15-17]. В кожній такій лабораторії існує відповідний пакет регламентної документації, частина з якої є конфіденційною, а також колекція еталонів дорогоцінного каміння. Цей комплекс дозволяє досягти відтворюваності в результатах оцінки якості дорогоцінних каменів, яка здійснюється незалежними та спеціально підготовленими експертами, а також забезпечити реляцію показників якості до вартісних показників на ринку. Це також опосередковано свідчить як про об’єктивність оцінки якості, так й про точність прогнозування вартості.

Найбільш відомими є технічні умови та регламенти таких світових центрів сертифікації дорогоцінного каміння як Гемологічний Інститут Америки в Карлсбаді, Гемологічний інститут Вищої Алмазної Ради в Антверпені, Гемологічний центр в Ідар-Оберштайні (Німеччина) та Гохран в Росії [1]. В Україні сертифікація дорогоцінних каменів здійснюється на добровільній основі $[10,11]$ та на основі технічних умов, затверджених згідно 3 чинним законодавством, які $\epsilon$ розробками та інтелектуальною власністю Державного гемологічного центру України й приватних експертнодіагностичних лабораторій. Отже, вимогу щодо відповідності практик сертифікації дорогоцінного каміння між економічно розвинутими країнами світу та українськими експертними організаціями нині можна вважати виконаною.

Водночас, на початку XXI століття виникають особливі умови на ринку дорогоцінних каменів, які у значній мірі нівелюють цінність існуючих систем сертифікації, які практикувалися протягом останніх ста років. Причиною цього стали такі нові обставини:

1. Глобалізований ринок, повністю позбавився дефіцитарних явищ й характеризується відкритістю інформації про обсяги ринків та доступністю потенційного споживача до будь-яких дорогоцінних каменів.

2. Подолано монополізм окремих продавців на ринку коштовних каменів, чим створені нові можливості для впливу потенційних покупців на вартість дорогоцінного каміння у пропозиції.

3. Спостерігається знецінення інформації, поданої в офіційних добірках рекомендованих показників вартості (рекомендовані показники 
вартості або індикаторні показники вартості відкрито публікують провідні лабораторії світу), пов'язане 3 наддинамічним та конкурентним характером змін комерційної вартості на дорогоцінне каміння у пропозиції (комерційні показники встановлюють власники - видобувні, огранувальні та дилерські компанії). Коливання цін відбувається протягом дуже невеликих проміжків часу і сягає рівнів $30-50$ відсотків.

4. Поява на ринку великої кількості каменів, які $\epsilon$ штучно облагородженими (штучне покращення якості) за допомогою сучасних технологій. Ці камені є досить дешевими. Регламенти оцінки якості таких каменів відсутні. Швидке виявлення ознак облагородження нині доступне майже усім учасникам ринку й, у більшості випадків, не вимагає сертифікації каменів в спеціалізованих гемологічних установах.

5. Конфіденційність технічних регламентів провідних лабораторій та недоступність еталонів нині протирічить законам, які встановлюють вимоги відкритості інформації для кінцевого споживача.

6. Державне регулювання вартісних показників на дорогоцінне каміння протирічить свободам громадян у задоволенні їх гуманітарних потреб.

7. Зростання додаткових витрат, пов'язаних з послугами з пересилки, страхуванням та сертифікацією дорогоцінних каменів на фоні здешевлення основної маси дорогоцінних каменів.

8. Гостра потреба здійснювати зрозумілу для усіх учасників ринку попередню оцінку якості й вартості дорогоцінних каменів ще до укладення контрактів та здійснення їх сертифікації.

9. Потреба в міжнародній уніфікації процесу оцінки (без прив'язки до стандартів національних лабораторій) й прозорості усіх операцій, пов'язаних 3 нею, а також з метою спрощення роботи міжнародних виставок-ярмарків, які набули популярності й проходять щомісяця в багатьох країнах світу.

10. Потреба створення уніфікованих інтернет-додатків для оперативної роботи з оцінки якості та прогнозування вартості дорогоцінного каміння.

Нові проблеми та потреби споживачів, які виникли у зв'язку 3 процесами глобалізації й інформатизації, збільшенням обсягів товарних ринків та пришвидшенням обігу цінностей, характеризується тим, що традиційний порядок сертифікації дорогоцінного каміння за якістю в операціях купівлі-продажу втрачає сенс, адже втрачають сенс рекомендовані показники вартості, які виконували в минулому роль мотиваторів на монополізованих ринках. 
Коли ми отримуємо сертифікат, який засвідчує високу якість дорогоцінного каменю й, відповідно, його високу прогнозовану вартість, ми нині розуміємо, що існує цілком реальна можливість придбати подібний камінь за ціною на 40 і більше відсотків нижчою і без витрат на сертифікат. Відтак, мотивація до дорогої сертифікації здешевленого та дуже поширеного на ринку дорогоцінного каміння поступово втрачає сенс так само, як й рекомендовані вартісні показники. Атестат якості є важливим для кінцевого споживача тільки тоді, коли не містить конфіденційної складової й може бути доказом високої вартості. Однак, гарантом якості виступає гемологічна лабораторія, яка діє лише як консультант й згідно з сучасною юридичною практикою не несе відповідальності за можливу вартість каменів й, навіть, за результат визначення їх якості (якість визначають за конфіденційними регламентами, отже, експерт відповідає лише за дотримання регламенту при визначенні якості, але не за якість).

Проблемність створює також та обставина, що в сучасному глобалізованому світі з уніфікованою банківською системою, фінансовим ринком й чітко визначеним курсом валют вартість дорогоцінного каміння $\epsilon$ нині ні до чого не прив'язаною. Це, в цілому, є позитивним й притаманним вільному ринку явищем, однак, обмежує кінцевого споживача в компетентності щодо процесів ціноутворення в фінансових операціях, адже донині дорогоцінні камені продовжують виконувати, крім іншого, акумулюючу фінансову функцію.

Описані проблеми є проявом трансцендентності (відірваності й незалежності) традиційних оцінок якості й вартості дорогоцінного каміння від реальних торгівельних практик, яка не може бути подоланою за допомогою його атестації в провідних гемологічних лабораторіях. Отже, потрібні нові, абсолютно прозорі й прості в практичному застосуванні алгоритми для визначення якості дорогоцінних каменів, які $\epsilon$ повністю релятивними однозначно визначеними щодо прогнозованих показників їх вартості, а також повністю кореспондентними до фінансових можливостей потенційних покупців.

Аналіз останніх досліджень, у яких започатковано вирішення проблеми. $\mathrm{У}$ роботі [2] зроблено розподіл вартісних показників на ювелірні вироби з діамантами, які представлені на ринку України, та виділено групи виробів з подібними якісними та вартісними показниками. Враховуючи, що ринок дорогоцінних каменів має свої відмінності, тому доцільно провести дослідження визначення вартості цих товарів. 
Цілі статті полягають в демонстрації одного з можливих і, водночас, принципово нового підходу до оцінки якості й прогнозування вартості дорогоцінного каміння для задоволення потреб бізнесу та потенційних споживачів, який спрощує та повністю візуалізує усі особливості процедури атестації якості дорогоцінних каменів без замовлення послуг сертифікаційних лабораторій, а також дає можливість здійснювати обгрунтоване прогнозування вартості безпосередньо пов'язуючи його з станом фінансового ринку в цілому.

Об'єкт дослідження - дорогоцінне каміння (аметисти, турмаліни, смарагди, топази, рубіни, сапфіри), представлене на ринку України.

Методи дослідження. Для прогнозування вартості дорогоцінного каміння було використано методи регресійного аналізу.

Виклад основного матеріалу дослідження з повним обгрунтуванням отриманих наукових результатів. Метод вирішення поставленої проблеми полягає в застосуванні одного з загальних принципів товарознавства, який формулюється таким чином: «Чим більше позитивної інформації про товар, тим вище його якість й, відповідно, вартість» [2,4-6]. Згідно 3 поданим формулюванням, прогнозована вартість (C) описується формулою:

$$
C=\alpha 2^{n}
$$

де $\quad \alpha$-коефіцієнт пропорційності й одночасно база оцінки;

$n$ - кількість позитивної інформації у бітах, яка обраховується як добуток показників якості в протоколі описаному нижче.

Розподіл вартісних показників на ринку дорогоцінних каменів завжди відповідає описаному вище виразу, у чому легко пересвідчитися, здійснюючи аналіз вартісних показників рубінів, сапфірів, топазів та інших дорогоцінних каменів. Це пояснюється двома причинами.

Перша причина - кількість якісних та великих (й дуже цінних) каменів у природі $\epsilon$ дуже обмеженою, а камені низької та середньої якості видобуваються в надлишковій кількості. Тенденція розподілу кількісних характеристик різних за якістю дорогоцінних каменів, що представлені на світовому ринку, завжди описується нелінійною експоненціальною функцією, близькою до зазначеної вище.

Друга причина - кількість заможних потенційних покупців на світовому ринку є дуже обмеженою, у той час як кількість потенційних покупців на дешеві камені - великою. Це кореспондується з кривою розподілу фінансових 
можливостей за М.О.Лоренцом [2], яка також описує розподіл витрат на задоволення гуманітарних потреб особистості за допомогою експоненціальної функції.

На рис. 1 наведено графік розподілу питомих вартісних показників у доларах США за один карат на природні та облагороджені дорогоцінні камені, представлені на ринку України станом на лютий-травень 2017 року.

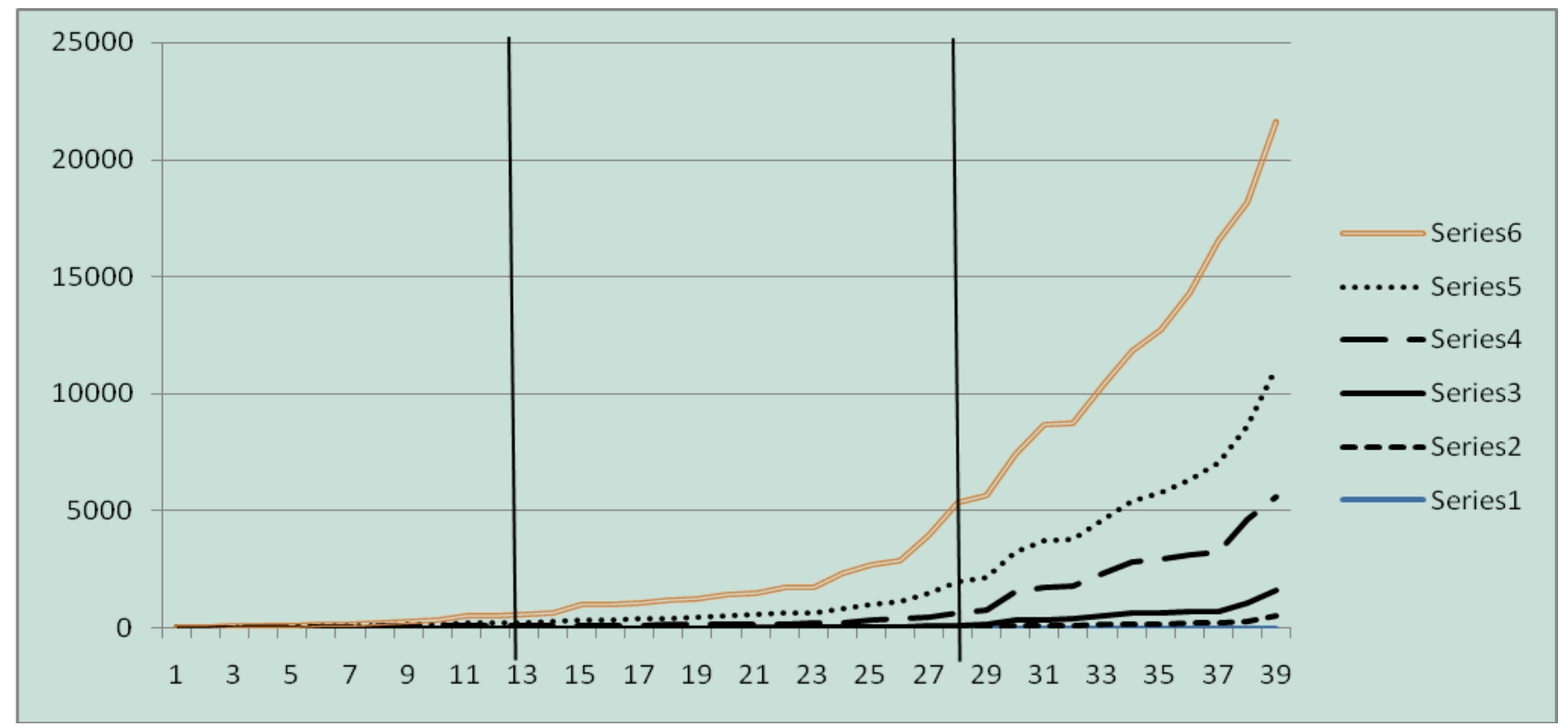

Рис 1. Розподіл питомих показників вартості дорогоцінних каменів представлених на ринку Украӥни, що подані у порядку зростання - для аметистів (ряд

1- найнижчі показники питомої вартості- від 0,2 до 50 доларів США за карат), топазів (ряд 2, питомі показники вартості яких лежать в діапазоні від 1 до 550 доларів

США за карат), турмалінів (ряд 3, питомі показники вартості яких лежать в діапазоні від 5 до 1200 доларів США за карат), смарагдів (ряд 4, питомі показники вартості яких лежать в діапазоні від 10 до 5000 доларів США за карат) рубінів (ряд 5, питомі показники вартості яких лежать в діапазоні від 10 до 10000 доларів США за карат) та сапрірів, які мають найвищі показники питомої вартості, які лежать в діапазоні від 10 до 20000 доларів США за карат (ряд 6). Вісь абсцис-порядок вартості, визначений в таблицях вихідних даних, які відљзеркалюють сукупну характеристику якості дорогоцінних каменів. Вісь ординат - показники питомої вартості у доларах

США за один карат. Вертикальними лініями позначені інтервали з різними тенденціями до зростання у співвідниеннях «якість - питома вартість" дорогоцінних каменів. Джерело: http://prom.ua/p458404853; https://gemlovers.ru ; http://www.redkiekamni.ru/kamni/; http://sad-kristallov.com.ua; www.gems.com.ua; www.ua.all.biz/uk

Графіки розподілу показників питомої вартості були побудовані на основі вивчення баз інформації про представлені до продажу сапфіри, рубіни, смарагди, топази, турмаліни та аметисти. Для побудування графіків використані інтернет- джерела. 
Для врівноваженого та повного врахування якості дорогоцінних каменів у всіх їх якісних показниках, ми пропонуємо використовувати не традиційну сукупність характеристик - розмір, колір, чистота та інші не пов'язані між собою показники з різними характеристиками значимості (впливу на кінцевий результат), а уніфіковану інтегральну характеристику - індекс якості, величина якого дорівнює показнику сукупної кількості позитивної інформації про їх якість й описується представленою вище формулою (1).

Усі основні ознаки якості дорогоцінних каменів, згідно з цим підходом, мають однакову значимість й обліковуються за допомогою спеціального протоколу, описаного в табл. 1, який являє собою спеціально спроектовану i фрагментовану напівкількісну шкалу якості.

Таблиия 1

\section{Протокол оцінки якості дорогоцінних каменів}

\begin{tabular}{|c|c|c|c|}
\hline $\begin{array}{c}\text { Назва критерію оцінки } \\
\text { якості }\end{array}$ & $\begin{array}{c}\text { Короткий опис системи } \\
\text { фрагментації шкали } \\
\text { якості за описаним } \\
\text { критерієм }\end{array}$ & $\begin{array}{c}\text { Індекс якості за } \\
\text { відповідним } \\
\text { критерієм }\end{array}$ & $\begin{array}{c}\text { Результат } \\
\text { оцінки }\end{array}$ \\
\hline 1 & 2 & 3 & 4 \\
\hline \multirow[t]{5}{*}{ 1. Розміри каменю } & До 0,1 карата & 0,25 & \multirow{5}{*}{4} \\
\hline & Від 0,1 до 1 карата & 0,5 & \\
\hline & Від 1 до 3 карат & 1 & \\
\hline & Від 3 до 7 карат & 2 & \\
\hline & Більше 7 карат & 4 & \\
\hline \multirow[t]{3}{*}{ 2. Насиченість кольору } & Дуже слабко насичений & 0,5 & \multirow{3}{*}{2} \\
\hline & Слабко насичений & 1 & \\
\hline & Добре насичений & 2 & \\
\hline \multirow[t]{3}{*}{ 3. Світлота } & $\begin{array}{l}\text { Темний відтінок } \\
\text { відсутній }\end{array}$ & 2 & \multirow{3}{*}{2} \\
\hline & Темний відтінок слабкий & 1 & \\
\hline & $\begin{array}{l}\text { Темний відтінок добре } \\
\text { помітний }\end{array}$ & 0,5 & \\
\hline \multirow[t]{4}{*}{ 4. Чистота } & $\begin{array}{l}\text { Критично низький рівень } \\
\text { чистоти }\end{array}$ & 0,25 & \multirow{4}{*}{0,5} \\
\hline & Чистота низька & 0,5 & \\
\hline & Середній рівень чистоти & 1 & \\
\hline & Високий рівень чистоти & 2 & \\
\hline \multirow[t]{3}{*}{ 5. Якість огранування } & Низька & 0,5 & \multirow{3}{*}{1} \\
\hline & Середня & 1 & \\
\hline & Висока & 2 & \\
\hline
\end{tabular}


Товарознавчий вісник. - 2018. - Випуск 11.

Продовження табличі 1

\begin{tabular}{|c|c|c|c|}
\hline 1 & 2 & 3 & 4 \\
\hline \multirow{3}{*}{$\begin{array}{l}\text { 6. Складність } \\
\text { огранування }\end{array}$} & Примітивне & 0,5 & \multirow{3}{*}{0,5} \\
\hline & Просте & 1 & \\
\hline & Складне & 2 & \\
\hline \multirow{3}{*}{$\begin{array}{l}\text { 7. Наявність особливих } \\
\text { оптичних властивостей }\end{array}$} & Слабкі або відсутні & 1 & \multirow{3}{*}{1} \\
\hline & Середні & 2 & \\
\hline & Сильні (яскраві) & 4 & \\
\hline \multirow{3}{*}{$\begin{array}{l}\text { 8. Відповідність } \\
\text { кольору культурним } \\
\text { традиціям }\end{array}$} & Повністю не відповідає & 0,5 & \multirow{3}{*}{2} \\
\hline & Слабка відповідність & 1 & \\
\hline & Відповідає & 2 & \\
\hline \multirow{4}{*}{$\begin{array}{l}\text { 9. Наявність ознак } \\
\text { штучного покращення } \\
\text { якості }\end{array}$} & $\begin{array}{l}\text { Ознаки покращення якості } \\
\text { домінують }\end{array}$ & 0,125 & \multirow{4}{*}{1} \\
\hline & Ознаки покращення якості значні & 0,25 & \\
\hline & Ознаки покращення якості незначні & 0,5 & \\
\hline & Ознаки покращення якості відсутні & 1 & \\
\hline \multicolumn{3}{|c|}{ Сукупний індекс якості «К» (добуток усіх показників у стовпчику 4) } & 8 \\
\hline
\end{tabular}

Отже, суттєвою відмінністю нового підходу до інтегральної оцінки якості дорогоцінних каменів згідно із запропонованим алгоритмом $\epsilon$ рівноважливість усіх критеріїв оцінки та визначення якості в чітко визначених одиницях виміру - кількості позитивної інформації про товар. Такий підхід до оцінки каменів є також принципово відмінним від традиційних способів проектування шкал якості, головним недоліком яких є відсутність формульно визначеної реляції між якістю та прогнозованою вартістю, що грубо відділяє сучасну систему сертифікації від потреб реального ринку.

3 протоколу випливає, що інтегральний індекс якості описується дуже в широкому інтервалі значень. Найбільше значення відповідає показнику 64, а найменше $-3,81 \times 10^{-6}$. Звичайно, в природі не буває абсолютно якісних або неякісних каменів, однак, теоретично шкала повинна описувати усі допустимі граничні оцінки.

Отже, якість дорогоцінних каменів повинна визначатися за допомогою індексу, який є сумою позитивної інформації про товар й розраховується на основі спеціально спроектованої шкали, описаної в наведеному вище протоколі для обліку якісних характеристик [7].

Позначені на рис.1 інтервали (вертикальні лініі) необхідні для більш точного прогнозування вартості згідно 3 встановленою якістю каменів. Інтервали віддзеркалюють уявлення про три основні товарознавчі групи каменів: «природні камені низького рівня якості та камені облагороджені», «камені природні середньої якості», «камені природні високої якості». 
Зауважимо, що частина критеріїв, наведених у представленому вище протоколі оцінки якості, має контраверсійну природу, тобто віддзеркалює ту частину інформації, яка в цілому погіршує показник сукупної оцінки якості індекс якості є меншим 1 [7]. Так, дорогоцінні камені, вага яких є меншою 0,1 карата, використовують в ювелірних виробах переважно лише для підвищення декоративності і виразності основного художнього проекту. Ці камені $\epsilon$ недорогими й тому не можуть розглядатися як «акумулятор фінансів». Отже, вони, згідно представленого вище протоколу, оцінюються за допомогою сукупності контраверсійних оцінок.

На рис. 1 увесь інтервал питомих показників вартості дорогоцінних каменів поділений на три субінтервали за допомогою вертикальних ліній, що дозволяє виділити відповідні товарознавчі групи якості для кожного 3 поіменованих каменів. Перша, яка представляє найменші питомі показники вартості, описує дорогоцінні камені задовільної якості, а також ті, якість яких була суттєво покращеною за допомогою технологій облагородження. Друга камені середньої якості, які не мають слідів штучного облагородження, однак, мають невеликі вади забарвлення (слабка насиченість, зменшена світлота або зональність), можуть мати поодинокі включення сторонніх мінералів, характеризуватися недосконалим огрануванням тощо. Третя - камені високої якості.

Кожна 3 названих товарознавчих груп якості дорогоцінних каменів посідає своє місце на ринку та відповідає певному рівню задоволення гуманітарних потреб особистості. Крім того, кожна група орієнтована на потенційного покупця з визначеним рівнем фінансових можливостей. Описані товарознавчі групи характеризуються власною базою оцінки, кореспондентною з відповідним показником рівня середньої заробітної плати на території тієї чи іншої держави та показником середніх витрат громадян на задоволення гуманітарних потреб.

В Україні на задоволення гуманітарних потреб (культура та відпочинок) громадяни використовують не більше 2 відсотків річних статків [12]. Відтак, враховуючи показники середньорічних заробітків, можна прогнозувати доступність тих чи інших каменів та виробів з ними громадянам та планувати обсяги їх постачання на ринок за адаптованими цінами. Саме такий підхід в умовах перенасичення ринку пропозиціями 3 продажу дорогоцінних каменів та виробів з ними $є$ найбільш виправданим, а ще він не потребує традиційної сертифікації більшої частини каменів задовільної, середньої й високої якості у всесвітньо відомих гемологічних лабораторіях. 
Для аналітичного дослідження представлених графіків розподілу питомих показників вартості (рис. 1) були проведені розрахунки параметрів апроксимуючих сплайн-функцій, які найкращим чином описують відповідні тенденції за допомогою методу найменших квадратичних відхилень К.Ф.Гауса. В результаті були визначені параметри рівнянь (табл. 2), на основі яких можна здійснювати прогнозування питомої вартості - визначати рекомендовані рівні вартості, що будуть кореспондованими до визначеного показника сукупної якості (табл.1) та рівня фінансових можливостей потенційних споживачів. Якість апроксимації, розрахована за К.Пірсоном, характеризується дуже високими показниками - від 0,97 до 0,99 одиниць.

Таблиия 2

\section{Розрахункові показники баз оцінки для товарознавчих груп} дорогоцінних каменів

\begin{tabular}{|l|c|c|}
\hline Товарознавча група & $\begin{array}{c}\text { База оцінки першої групи } \\
\text { у доларах США за один } \\
\text { карат }\end{array}$ & $\begin{array}{c}\text { База оцінки другої та третьої } \\
\text { групи у доларах США за один } \\
\text { карат }\end{array}$ \\
\hline Аметист & 0,2 & 0,2 \\
\hline Топаз & 1,1 & 4,4 \\
\hline Турмалін & 4,8 & 9,6 \\
\hline Смарагд & 9,6 & 19,3 \\
\hline Рубін & 9,7 & 39 \\
\hline Сапфір & 10 & 80 \\
\hline
\end{tabular}

Враховуючи те, що на ринку дорогоцінного каміння та ювелірних виробів не представлені камені критично низької якості (технічна якість), які характеризуються вкрай низькими показниками сукупного індексу якості «К» i описані в товарознавчій групі 1, а також камені ідеальної якості (3 показником сукупного індексу якості 32) в товарознавчій групі 3, визначення рекомендованих показників питомої вартості можна здійснювати за допомогою спеціальних таблиць (табл. 3). Тобто, усі компоненти процесу прогнозування якості та вартості дорогоцінного каміння $є$ зрозумілими (однозначно тлумачаться), не передбачають наявності конфіденційної інформації, спираються на доступні джерела інформації та прості у практичному застосуванні. Отже, завдання, поставлені в меті цієї роботи, повністю вирішені.

Розрахунки прогнозної вартості можна здійснити також за допомогою формули (2):

$$
C=B \times K x V
$$


де $C$-прогнозована вартість дорогоцінного каменю;

$B$ - база оцінки згідно таблиці 3 ;

$K$ - сукупний індекс якості;

$V$ - вага каменю в каратах (1 карат $=0,2$ грамів).

Таблиця 3

Прогнозні показники вартості дорогоцінних каменів*

\begin{tabular}{|c|c|c|c|c|c|c|c|c|}
\hline \multirow{3}{*}{$\begin{array}{c}\text { Вагова група } \\
\text { каменів }\end{array}$} & \multicolumn{8}{|c|}{ Сукупний індекс якості «К» } \\
\hline & \multicolumn{3}{|c|}{ Перша група } & \multicolumn{3}{|c|}{ Друга група } & \multicolumn{2}{|c|}{ Третя група } \\
\hline & 0,25 & 0,5 & 1 & 2 & 4 & 8 & 16 & 32 \\
\hline \multicolumn{9}{|c|}{ Аметисти } \\
\hline До 0,1 карата & & & & 0,2 & 0,4 & 0,8 & 1,6 & 3,2 \\
\hline Від 0,1 до 1 карата & & & 0,2 & 0,4 & 0,8 & 1,6 & 3,2 & 6,4 \\
\hline Від 1 до 2 карат & & 0,2 & 0,4 & 0,8 & 1,6 & 3,2 & 6,4 & 12,8 \\
\hline Від 2 до 7 карат & 0,2 & 0,4 & 0,8 & 1,6 & 3,2 & 6,4 & 12,8 & 25,6 \\
\hline Більше 7 карат & 0,4 & 0,8 & 1,6 & 3,2 & 6,4 & 12,8 & 25,6 & 51,2 \\
\hline \multicolumn{9}{|c|}{ Топази } \\
\hline \multicolumn{9}{|l|}{ До 0,1 карата } \\
\hline Від 0,1 до 1 карата & & 1,1 & 2,2 & 4,4 & 8,8 & 17,1 & 34,2 & 68,4 \\
\hline Від 1 до 2 карат & 1,1 & 2,2 & 4,4 & 8,8 & 17,1 & 34,2 & 68,4 & 136,8 \\
\hline Від 2 до 7 карат & 2,2 & 4,4 & 8,8 & 17,1 & 34,2 & 68,4 & 136,8 & 275,6 \\
\hline Більше 7 карат & 4,4 & 8,8 & 17,1 & 34,2 & 68,4 & 136,8 & 275,6 & 551,2 \\
\hline \multicolumn{9}{|c|}{ Турмаліни } \\
\hline До 0,1 карата & & & & 4,8 & 9,6 & 19,2 & 38,4 & 76,8 \\
\hline Від 0,1 до 1 карата & & & 4,8 & 9,6 & 19,2 & 38,4 & 76,8 & 153,7 \\
\hline Від 1 до 2 карат & & 4,8 & 9,6 & 19,2 & 38,4 & 76,8 & 153,7 & 307,5 \\
\hline Від 2 до 7 карат & 4,8 & 9,6 & 19,2 & 38,4 & 76,8 & 153,7 & 307,5 & 615 \\
\hline Більше 7 карат & 9,6 & 19,2 & 38,4 & 76,8 & 153,7 & 307,5 & 615 & 1230 \\
\hline \multicolumn{9}{|c|}{ Смарагди } \\
\hline До 0,1 карата & & & 9,6 & 19,3 & 38,6 & 77,3 & 154,6 & 309,3 \\
\hline Від 0,1 до 1 карата & & 9,6 & 19,3 & 38,6 & 77,3 & 154,6 & 309,3 & 618,7 \\
\hline Від 1 до 2 карат & 9,6 & 19,3 & 38,6 & 77,3 & 154,6 & 309,3 & 618,7 & 1237,5 \\
\hline Від 2 до 7 карат & 19,3 & 38,6 & 77,3 & 154,6 & 309,3 & 618,7 & 1237,5 & 2475 \\
\hline Більше 7 карат & 38,6 & 77,3 & 154,6 & 309,3 & 618,7 & 1237,5 & 2475 & 4950 \\
\hline \multicolumn{9}{|c|}{ Рубіни } \\
\hline До 0,1 карата & & 9,7 & 19,5 & 39 & 78,1 & 156,2 & 312,5 & 625 \\
\hline Від 0,1 до 1 карата & 9,7 & 19,5 & 39 & 78,1 & 156,2 & 312,5 & 625 & 1250 \\
\hline Від 1 до 2 карат & 19,5 & 39 & 78,1 & 156,2 & 312,5 & 625 & 1250 & 2500 \\
\hline Від 2 до 7 карат & 39 & 78,1 & 156,2 & 312,5 & 625 & 1250 & 2500 & 5000 \\
\hline Більше 7 карат & 78,1 & 156,2 & 312,5 & 625 & 1250 & 2500 & 5000 & 10000 \\
\hline \multicolumn{9}{|c|}{ Сапфipи } \\
\hline До 0,1 карата & & 20 & 40 & 80 & 161 & 323,2 & 646 & 1292 \\
\hline Від 0,1 до 1 карата & 10 & 40 & 80 & 161 & 323 & 646 & 1292 & 2585 \\
\hline Від 1 до 2 карат & 40 & 80 & 161 & 323 & 646 & 1292 & 2585 & 5171 \\
\hline Від 2 до 7 карат & 80 & 161 & 323 & 646 & 1292 & 2585 & 5171 & 10342 \\
\hline Більше 7 карат & 161 & 323 & 646 & 1292 & 2585 & 5171 & 10342 & 20684 \\
\hline
\end{tabular}


Середня заробітна плата громадянина України станом на 01.01.2017 року становила 6008 гривень [14]. Відтак, в 2017 році, у разі збереження тенденції зростання показника середньої заробітної плати, річний дохід складатиме не менше 72096 гривень, а 2 відсотки від нього - 1442 гривні або 54,5 доларів США (за курсом Національного банку України станом на 18.05.2017 року). Саме цей рівень вартісних показників на коштовне каміння буде найбільш доступним для більшої частини громадян України. Відтак, розрахунковий показник можливих витрат на задоволення гуманітарних потреб - це камені першої та другої товарознавчої групи, а також найбільш дешеві камені третьої групи. Звичайно, дорогі камені теж будуть купувати, але у дуже обмеженій кількості найбільш заможні громадяни.

Усвідомлюючи, що реальний бізнес повинен враховувати фінансові можливості потенційних покупців, ми пропонуємо використовувати у якості бази оцінки дорогоцінних каменів саме показник двовідсоткової ставки середньорічної заробітної плати громадян України. Для цього слід знайти в табл. 3, наприклад, величину вартості смарагдів, найбільш близьку до вище вказаного рівня (54,5 доларів США) та траспонувати усі дані, які стосуються смарагдів, відносно цього показника. Результат такої процедури представлено в табл. 4. Причому, у якості найбільш близького показника доречно використати меншу величину, адже більша буде відповідати завищеному показнику середньої заробітної плати.

Таблиия 4

Прогнозні (індикаторні) показники вартості смарагдів, кореспондовані до фінансових можливостей потенційних покупців

\begin{tabular}{|l|c|c|c|c|c|c|c|c|}
\hline \multirow{2}{*}{$\begin{array}{c}\text { Вагова група } \\
\text { каменів в каратах }\end{array}$} & \multicolumn{7}{|c|}{ Перша група } & \multicolumn{2}{c|}{ Друга група } & \multicolumn{2}{c|}{ Третя група } \\
\cline { 2 - 10 } & 0,25 & 0,5 & 1 & 2 & 4 & 8 & 16 & 32 \\
\hline До 0,1 карата & & & 6,8 & 13,6 & 27,2 & 54,5 & 109 & 218 \\
\hline Від 0,1 до 1 карата & & 6,8 & 13,6 & 27,2 & 54,5 & 109 & 218 & 436 \\
\hline Від 1 до 2 карат & 6,8 & 13,6 & 27,2 & 54,5 & 109 & 218 & 436 & 872 \\
\hline Від 2 до 7 карат & 13,6 & 27,2 & 54,5 & 109 & 218 & 436 & 872 & 1744 \\
\hline Більше 7 карат & 27,2 & 54,5 & 109 & 218 & 436 & 872 & 1744 & 3488 \\
\hline
\end{tabular}

* Прогнозні (індикаторні) показники вартості смарагдів наведені в доларах США за карат. Пусті клітинки вказують на відсутність на ринку маленьких каменів низької якості у зв'язку з нерентабельністю їх виготовлення. 
Таким чином, є сенс коригувати усі представлені вище таблиці, крім того, 3 метою їх актуалізації в рамках відповідного інтервалу часу коригування слід проводити не рідше ніж два рази на рік.

Співвідношення між прогнозними показниками вартості на смарагди, розрахованими за даними реального ринку та показниками, які є найбільш прийнятними для потенційних споживачів, ілюстровано графіком на рис. 2.

Доцільно також корегувати таблицю розрахункових показників баз оцінки у відповідності 3 транспонованими таблицями, що враховують показники фінансових можливостей потенційних покупців. Це легко зробити користуючись вже вище описаним підходом.

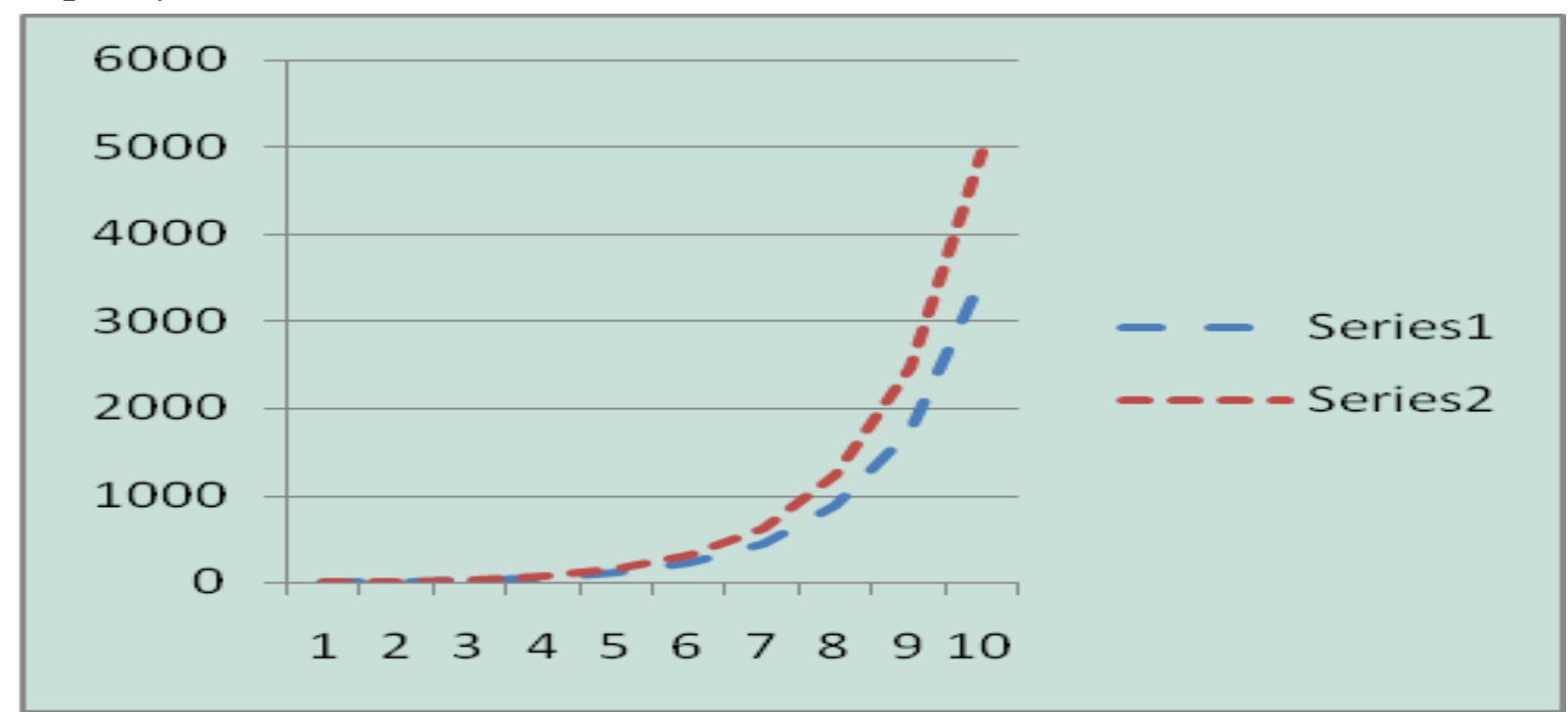

Рис. 2. Співвідночення прогнозованих показників вартості смарагдів: отриманих в результаті аналізу ринку (ряд 2) та врахування фінансових можсливостей потенційних покупців (ряд 1). Вісь ординат - вартість каменів відповідного розміру та якості. Вісь абсцис - порядок вартості каменів від найменшої до найвищої дискретної величини згідно поданих вище таблиць

Для прикладу розглянемо процедуру прогнозування вартості смарагду, поданого на рис.3. Характеристики якості каменю: вага - 6,3 карата, огранювання смарагдове (просте); сукупний показник якості - 8 (розраховано відповідно до протоколу, наведеному в табл.1)

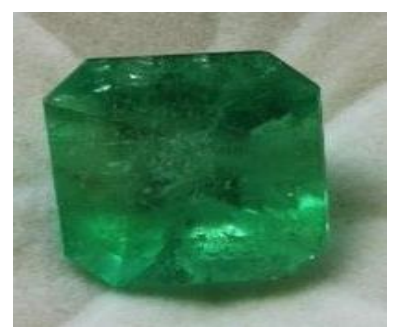

Рис. 3. Огранений смарагд хорочої якості з Бразилії 
Прогнозована вартість, обчислена за результатами аналізу ринку за допомогою формули (2), є такою: $\mathrm{C}=\mathrm{B} \times \mathrm{K}$ x V $=618,7$ × 8 × 6,3 $=31182,48$ (доларів США). Прогнозована вартість, обчислена на основі показників фінансових можливостей потенційних покупців, є значно меншою: $\mathrm{C}=436 \mathrm{x}$ 8 х 6,3 = 21974,4 (доларів США). Визначений діапазон повністю відповідає рівням вартісних показників на споріднені камені, які виставлені на продаж на сучасному ринку [9].

Висновки та перспективи подальших досліджень. Результати аналізу розподілу питомих вартісних показників на дорогоцінні камені на ринку України та розрахунки параметрів, що описують відповідні тенденції у співвідношеннях «якість-вартість», свідчать:

- про доцільність та ефективність використання запропонованого спрощеного підходу до обліку якісних характеристик каменів у відповідності з описаним протоколом;

- про можливість обчислення прогнозних показників вартості на дорогоцінні камені 3 урахуванням двох факторів - аналізу ринку та врахування особливостей розподілу показників рівнів фінансових можливостей потенційних покупців;

- про ефективність та оперативність простих алгоритмів оцінки дорогоцінних каменів в практиках суб'єктів оціночної діяльності.

\section{Література}

1. Бочаров А. М. Классификация алмазного сырья по системе SITY. Учебное пособие / А. М. Бочаров, В. А. Симоненков, В. Е. Тимошенков. - М., Гиналмаззолото, 1991. $-40 \mathrm{c}$.

2. Індутний В.В. Застосування функції розподілу Лоренца в товарознавстві / В. В. Індутний // Товари і ринки. - 2015. - № 2 (20). - С. 168-178.

3. Індутний В. В. Мережко Н. В., Піркович К. А. Аналіз ринку рубінів у якісних та вартісних показниках / В. В. Індутний, Н. В. Мережко, К. А. Пірковіч // Технічні науки та технології. - 2017. - № 2 (8). - С.66-73.

4. Індутний В. В. Оцінка пам'яток культури / В. В. Індутний. - К. : СПД Моляр С.В., 2009. $-537 \mathrm{c}$.

5. Індутний В. В. Ринки культурних цінностей: Порівняльний аналіз / В. В. Індутний // Вісник Національної академії керівних кадрів культури і мистецтв. - 2014. №1. - С. 19-27.

6. Індутний В. В. Формула Ральфа Хартлі й прогнозування вартості пам'яток культури / В.В. Індутний // Культура і сучасність: альманах. - 2014. - № 2. - С. 70-78.

7. Індутний В. В. Як оцінювати коштовності з дорогоцінних каменів та металів / В. В. Індутний, В. І. Татаринцев, В. І. Павлишин, Т. В. Індутна та інш. - К.: АЛМА, 2001. $268 \mathrm{c}$.

8. Кунц Дж. Камни-талисманы. Уникальные сведения о драгоценных камнях / Дж. Кунц. - М. : REFL-book; K.: Ваклер, 1997. - 287 с. 
9. Смарагди [Електронний ресурс]. - Режим доступу: https://gemlovers.ru/izumrud/stoimost-izumruda/.

10. Про затвердження Положення про реєстр власних i торгових назв дорогоцінного каміння, дорогоцінного каміння органогенного утворення, напівдорогоцінного і декоративного каміння з родовищ Україн: Наказ Міністерства фінансів України від 06.12. 2000 № 312 [Електронний ресурс]. - Режим доступу : http://zakon2.rada.gov.ua/laws/show/z0927-00.

11. Про затвердження Правил атестації дорогоцінного каміння, дорогоцінного каміння органогенного утворення , напівдорогоцінного і декоративного каміння: Постанова Кабінету Міністрів України від 06.09.2000 № 1396, в редакції від 01.03.2007 [Електронний pecypc]. - Режим доступу : http://zakon4.rada.gov.ua/laws/show/1396-2000-\%D0\%BF.

12. Рівень витрат на продукти харчування серед європейських країн [Електронний ресурс]. - Режим доступу: http://infolight.org.ua/content/u-2013-roci-seredievropeyskih-krayin-v-ukrayini-naybilshe-vitratili-na-produkti-harchuvannya-naymenshe-nakulturu.

13. Рид П. Дж. Геммологический словарь / П. Дж. Рид. - Л. : Недра, 1986. - 387c.

14. Сайт Міністерства фінансів України [Електронний ресурс]. - Режим доступу: http://index.minfin.com.ua/index/average/.

15. Смит Г. Драгоценные камни / Г. Смит. - М.: Мир, 1980. - 387 с.

16. Уолтерс Дж. Р. Все о драгоценных камнях / Дж.Р. Уолтерс. - М. : ЗАО БММ, 1999. - $160 \mathrm{c}$.

17. Шуман В. Мир камня : в 2 т. / В. Шуман. - М. : Мир, 1986. - 477 с.

Цель. Исследование основных принципов по формированию специальных протоколов о качестве и стоимости драгоченных камней на рынке Украины, а также построение математической модели для описания релящии «качество-стоимость» при осуществлении операщий прогнозирования их стоимости.

Методика. Для прогнозирования стоимости драгоценных камней были использованы стандартные методы регрессионного анализа.

Результаты. Представлень результаты анализа распределения удельных стоимостных показателей на драгоценные камни на рынке Украины. Выделены три товароведные группь качества для драгоценных камней: камни удовлетворительного качества, камни среднего качества, камни высокого качества.

Предложен универсальный индекс для оценки качества драгоценных камней, основанный на расчете количества позитивной информачии о них. Критерии для описания качества в терминах количества позитивной информации представлены в специальном протоколе. Предложено определять прогнозируемую стоимость драгоиенных камней с учетом финансовых возможностей потенциальных покупателей. Представлены примеры определения качества и прогнозирования стоимости драгоценных камней на основе предложенного алгоритма.

Научная новизна. Выделены три товароведные группы драгоценных камней по качественным характеристикам и установлены зависимости между их прогнозируемой стоимостью и порядком стоимости.

Практическая значимость. Разработан упрощенный подход к учету качественных характеристик камней, методика определения прогнозируемой стоимости драгоиенньх камней, которая дает возможность вычисления прогнозных показателей стоимости на 
драгоценные камни с учетом двух факторов - анализа рынка и учета особенностей распределения показателей уровней финансовых возможностей потенциальных покупателей.

Ключевые слова: драгоченные камни, прогнозируемая стоимость, универсальный индекс, специальный протокол.

Purpose. It is the investigation of basic principles on forming special protocols about the quality and value of gemstones on the market of Ukraine and building a mathematical model to describe the correlation "quality-value" in transactions predicting their value.

Methodology. The standard methods of regression analysis have been used for predicting the value of gemstones/

Findings. Results of the analysis of the distribution of specific value parameters of the gemstones in the Ukrainian market have been given. Three commodity groups have been selected: stones of satisfactory quality, stones of average quality, stones of high quality.

A new method of determining a universal index to evaluate the quality of gems, which based on the calculation of the number of positive information about the product are offered. Criteria for describing quality in terms of the number of positive information presented in a special protocol. Estimated value of gemstones is determined taking into account the financial capacity of potential buyers. Examples of determining the quality and value of gemstones prediction based on the proposed algorithm are represented.

Originality. Three commodity groups of gemstones on qualitative characteristics have been selected and the dependencies between their estimated value and order value have been established.

The practical value. The simplified approach to the accounting for the qualitative characteristics of gemstones and the method of determining the estimated value of gemstones, which allows to determine the estimated value of gemstones taking into account two factors such as the market analysis and the financial capacity of potential buyers has been developed.

Keywords: gemstones, estimated value,, universal index, special protocols.

Рекомендовано до публікаиії д.т.н., професором КНТЕУ Коптюхом Л.А.

Стаття надійшла в редакиію 15.12.2017 p. 